\title{
Women Chief Executives: The Political Catch-22 of Counterterrorism
}

\section{by Courtney Burns and Kyle T Kattelman}

\section{(cc) $\mathrm{BY}$}

This work is licensed under a Creative Commons Attribution 3.0 License.

\begin{abstract}
Do women chief executives experience more terrorist activity during their time in office? We are interested in exploring this question given the rise in the study of gender and conflict. We argue that women leaders experience higher levels of terrorist violence due to gender perceptions. Women leaders are perceived as conflict averse. Concomitantly, women leaders who respond forcibly against terrorist agitation run the risk of domestic political costs and possibly additional terrorist recruitment as a result of policies that deviate from gender norms. This political catch-22 results in a higher frequency of terrorist violence. We examine this relationship on instances of domestic terrorism from 1980-2011. The results confirm that women leaders experience terrorist violence more frequently.
\end{abstract}

\section{Introduction}

$\mathrm{W}$ hich leaders experience more terrorist activity than others? Previous research has attempted to answer this question through exploring the institutional constraints and behavior of chief executives. For example, it has been shown that autocrats with higher audience costs are expected to face more terrorism. [1] Moreover, countries that repress at higher rates may also see more terrorist activity. [2] We are interested in expanding the literature that examines when a regime or leader is more or less likely to be targeted by terrorist activity. In particular, we ask whether women chief executives are more likely to be targets. There are an increasing number of studies conducted on gender and terrorism from the terrorist's side of the conflict. To our knowledge, no study has examined the role of women in government and terrorist activity.

Benazir Bhutto was the first female prime minister elected in a Muslim state and served the country of Pakistan from 1988 to 1990 and from 1993 to 1996. She was assassinated by a suicide terrorist in 2007 when she had returned to Pakistan to campaign for the position of prime minister once again. Bhutto attained leadership of Pakistan through the party that her father established in the 1970s. During her tenure her family endured significant political violence along with a rise in terrorist attacks within the country. Corazon Aquino inherited two insurgencies with terrorist activity, one against the separatist Moro Muslims and one against the leftist National Democratic Front. She was able to bring the groups to the table for peace talks, but talks eventually failed when the government would not agree to all of the groups' demands. At what point do terrorists view their leader as more vulnerable or more willing to bend at the bargaining table? Does the gender of the leader influence their decisions?

Women leaders often face stereotypes regarding the types of policies they support or what their personality should be. In fact, women leaders must often maintain a hawkish personality in respect to foreign policy in order to be taken more seriously.[3] However, when it comes to the treatment of their own people, domestic 


\section{Journal of Terrorism Research}

audiences may expect a more caring and nurturing leader. Indeed, some post-conflict societies purposefully select a female leader because of these stereotyped traits. [4]

We argue that female chief executives seeking to counter terrorist organizations find themselves in a catch-22. As Winkler succinctly puts it, a catch-22 is “.... an idiom representing a no-win situation built on illogic and circular reasoning." [5] The logical trap for female leaders lies in two contradictory traits that they must exhibit simultaneously: compassion and hawkishness. They need to present a hard-lined face to the world, which violates gendered assumptions about women, and a soft façade to their people in order to demonstrate that they are also feminine.[6] This can be a difficult line to balance. We argue that this leaves women leaders vulnerable to domestic terrorist attacks. Female leaders that are perceived as warm and compassionate present a favorable target for terrorist organizations seeking quick capitulation from a leader that is averse to violence. Conversely, a hawkish response from a female leader can be perceived as overtly harsh, which can also possibly trigger a backlash of terrorist violence. This circular reasoning leaves female leaders at a unique loss when dealing in areas of national security. This research is important for two reasons. First, it sheds light on the catch-22 for female leaders and the unrealistic expectations that women be both traditionally masculine and traditionally feminine as a leader of a country. Second, it also demonstrates that terrorist groups, along with domestic populations, continue to stereotype women leaders. Furthermore, terrorist groups use these stereotypes, whether explicitly or inadvertently, in their calculations of whether to engage in terrorist activity.

The following section outlines existing theories concerning the relationship between female leaders and expectations of the public. The literature stresses that female leaders are evaluated differently according to gender stereotypes. Overall, female leaders are perceived as violence averse, which affects evaluations of strength on matters of foreign policy. To counter this impression, some female leaders behave in an overtly hawkish manner in the international arena.[7] Such behavior is also perceived in a gendered light, as it is not stereotypically assumed that women should behave aggressively, suggesting that a male leader would elicit a different reaction. This catch-22 leaves female leaders without an ideal response. We then tie this theory into the decision calculus of terrorist strategy, utilizing existing theories of cost-benefit analysis and backlash effects in the terrorist literature. Since terrorism is a tool of the weak, its strategy is often directed at soft, vulnerable targets. The gender of the executive can serve as a heuristic of vulnerability, based on gender stereotyping. However, terrorists can also direct their attacks in retaliation to perceived overaggressive counterterrorist actions. This backlash effect can also be perceived differently based on the gender of the executive. Strong counterterrorist action from a female leader can incense terrorists to a higher degree than would be if coming from the orders of a male executive. The political catch-22 for female leaders makes necessary decision-making even more difficult because perceptions of softness and aggressiveness are magnified for female executives, resulting in a higher frequency of terrorist violence regardless of strategy.

We test this theory on instances of domestic terrorism from 1980-2011, utilizing a set of the most commonly used independent variables of terrorist violence. The results confirm that women leaders experience terrorist violence more frequently. The point of this study is not to say that women leaders are weaker than men, but being aware that this calculation is happening could help lead to better methods at ensuring domestic and international security.[8]

\section{Gender, Preferences, and Stereotypes}

When invoking the notion of leadership, the public tends to believe that leadership traits include qualities 


\section{Journal of Terrorism Research}

such as aggression, competitiveness, dominance, rationality, and decisiveness. Particularly in times of terrorist threat, individuals find it psychologically calming and practically useful to place candidates who are perceived as strong leaders into positions of power.[9] For women, though, it may be harder to demonstrate these qualities because society tends to have different expectations for them than for men. Previous research has consistently shown that men and women are perceived in stereotyped ways; in other words men are associated with male traits and women are associated with female traits.[10] Male traits are usually in line with those of political leadership: dominance, aggression, rational, competitive. On the other hand, female traits are sometimes the opposite: caring, nurturing, compassionate, polite, and emotional. These traits are also particularly magnified under instances of low information.[11]

These stereotypes are not necessarily done with ill intention. In fact, extant research has examined the preferences of women in the aggregate, and to some extent, women leaders. Generally, findings on the preferences of women point to a gender gap where women are more averse to violence than men. Aggregate information on women both within countries and cross-nationally finds that women are less likely to support the use of force.[12] For example, in a 2012 Pew Global Studies survey, across 12 different countries women were far more against the use of drone strikes by the U.S. than men.[13] The ranges differed from a 31-point gap in Japan to a smaller 13-point gap in Uganda. This conforms to previous cross-national, gender gap opinions on the Gulf War, indicating a strong aversion to violence on the part of women that is independent of any single conflict.[14] Further, social psychology research has found that women appear to practice more prosocial behavior. That is, they are more likely to be socially sensitive, friendly, and concerned with other's welfare.[15] Other research posits that women are more likely to be cooperative and less "selfish" than men. [16]

In regards to women leaders, it has been argued that women leaders may initiate conflict behavior with other countries and increase defense spending, but this does not necessarily relate to how they view domestic audiences.[17] Interviews with prominent women in U.S. foreign policy reveal that some of these officials view foreign policy much differently than their male counterparts and are averse to violence. [18] Furthermore, cross-national research on women in parliament finds that when more women are in parliament, more woman-friendly policies are passed.[19] Often the interpretation of "woman-friendly" indicates spending on domestic concerns such as education, health care, and family leave policies. Moreover, when more women are in parliament a country is less likely to be hawkish in their foreign policy stance. [20] Given this information about women in the aggregate and women leaders, one can see why there may be stereotyped expectations of women chief executives.

However, research done in the context of U.S. elections has found that gender is not necessarily the goto heuristic of the public while evaluating candidates. Instead, several studies have shown that gender stereotypes must be activated through either a campaign commercial or story or security threat in order for voters to make assessments based on gender.[21] Holman, Merolla, and Zechmeister find an intersectional relationship between political party and gender for candidate evaluation during times of terrorist threat. Specifically, they find that a democratic woman will be evaluated harsher than a republican woman because of party issue ownership.[22] However, this research has only been done in the context of candidate evaluation during U.S. elections and not for sitting leaders. To our knowledge, no research has specifically found that gender does not play a role in the evaluation of a sitting leader. Further, extending partisanship findings in the United States to other countries is a contentious debate in political science. For example, party systems in East Asia did not develop in the same manner as the U.S., indicating differences in social cleavages and patterns of elite politics.[23] Other research finds that in the Netherlands, party identification was a post- 


\section{Journal of Terrorism Research}

election phenomenon and not something that voters made decisions with[24] In other words, while there does appear to be potential complicating factors with partisanship, gender, and candidate evaluation in the U.S. , these findings do not necessarily translate well cross-nationally.

In fact, most research has found that gendered expectations and stereotypes can work against women who seek positions of power. For example, Falk and Kenski find that when U.S. citizens believed that terrorism and national security were important policy areas, they were less likely to say that they would elect a woman to office.[25] This is primarily due to the fact that men more frequently match the stereotypes of leaders than women do.[26] Eagly, Makhijani, and Klonsky demonstrate that women are perceived more negatively by the public for exhibiting the same behavior as men.[27] This means that women acting assertively violate gendered expectations and they tend to be penalized more for this behavior.[28] To that end, women are subjected to more scrutiny as chief executive than men because they are not typically the people that come to mind when picturing those in power[29]

When faced with scrutiny, women will attempt to act more masculine to appear more capable in policy areas traditionally thought to be better handled by men.[30] These policy areas overwhelmingly include taxes and national security.[31] Women leaders may resort to more hawkish behavior when dealing with security, in order to make up for appearing too "soft" with domestic policies. Caprioli and Boyer state:

"Female leaders who have risen to power through a male-defined and male dominated political environment may well need to be more aggressive in crises than their male counterparts... women may also work harder to 'win'... because to appear and act feminine (and therefore weak) would be political suicide"[32]

In other words, a woman leader must exhibit masculine (aggressive, rational) traits in order to be taken seriously; however, we often expect women leaders to be both feminine (caring, nurturing, soft) and masculine at the same time.[33] Women leaders are faced with a political double bind. They must demonstrate masculine qualities to show that they are leaders, but this challenges traditional assumptions about them as women. So, they must also act traditionally feminine (cooperative, compassionate, nurturing) in order to show that they are not violating stereotypes.

Given that women leaders act hawkish to portray competence (masculinity/leadership), we posit that women will opt to demonstrate their feminine traits with their domestic audiences. For example, women, particularly in developing countries, are often elected after a conflict ends purely for the reason that they are stereotypically viewed as different in temperament than the men that got them into conflict.[34] One primary example is that of Liberia and Ellen Johnson Sirleaf. Sirleaf was elected following her activity in the transitional government after Charles Taylor was exiled from Liberia in 2003. Many people, primarily women, advocated for her candidacy simply because she was a woman and they thought she would do things differently.[35] Such a finding is not uncommon; several women have been elected to office directly following conflict because the citizens believe women represent the values of communication and cooperation.[36] This directly reflects the gender stereotype that women are more peaceful than men when it comes to the treatment of their own people.

Since women leaders must be able to demonstrate both masculine and feminine traits, a woman leader faces extra obstacles that a male leader may not. For example, when bargaining with dissatisfied non-state actors, these stereotypes may make them more likely to be targets for violence. The political catch-22 we posit finds responses for women leaders' complicated by needing to portray compassion to her domestic audience, and aggression and strength towards terrorist activity. As we discuss in the next section, women leaders may find 


\section{Journal of Terrorism Research}

themselves in a bind for how they can react.

\section{Terrorism and Gender Perceptions}

This study utilizes a definition of terrorism best captured by Enders and Sandler, who define terrorism as: "the premeditated use or threat to use violence by individuals or subnational groups in order to obtain a political or social objective through intimidation of a large audience beyond that of the immediate victims." [37] The two essential elements of this definition are the threat or presence of violence and a political or social motive. The political or social motive implies that terrorists are goal-oriented, rational actors. [38]

Why would a group resort to terrorism? Our understanding of the motivations behind terrorism has moved from an ideographic approach to one in which the factors of stimulus have largely diverged into institutional and societal elements[39] Researchers also model terrorism as a bargaining interaction between states and terrorist organizations, finding information inconsistencies and problems of credible commitment as contributing elements.[40] Utilizing the rational choice approach of cost-analysis, however, allows us to structure the decisions at a most basic level. Our working theory is based on Enders and Sandler's "substitution" model in which terrorists organizations deciding to substitute from terrorist to non-terrorist activities examine state efforts to either raise the price for terrorist attacks or lower the price of non-terrorist activities.[41] A high cost of terrorism manifests itself through antiterrorism laws, military action, and tighter security, while a lowered price of non-terrorist activities includes the easing of access to elections.[42]

This cost-benefit analysis supports the presence of the catch-22. It is theorized here that, due to outlined gender perceptions, the presence of a woman leader lowers the costs of terrorism relative to non-terrorist activities. This is because, under a female chief executive, her perceived aversion to violence due to stereotypes from the terrorists' perspective should result in a reluctance to raise the costs of terrorism by enacting stricter antiterrorism laws and engaging in the use of force. It is important to stress that this theory is centered on the terrorist organization's calculated reaction of the female leader. In effect, they are weighing the expected costs of engaging in terrorism based off of incomplete information. The presence of a female leader signals to the organization that the expected costs of a terrorist act will be lower vis-à-vis engaging in non-terrorist activities.

The reaction of the government to this terrorist activity is also critical. Scholars have found that when governments respond with repression, they are more likely to provide a broader audience base for the terrorists and could potentially hurt their ability to collect information on the group from the public.[43] This is, perhaps, counter intuitive for many regimes, and suggests that leaders must carefully choose the degree of severity when responding to terrorism. A weak response on the part of the state can trigger perceptions that a leader is incapable of dealing with the threat, while too harsh of a response can swell the ranks of terrorist organizations and even manifest in the form of retaliatory attacks.[44] When a state leader is threatened domestically, according to the "law of coercive responsiveness," it is more likely that violations of physical integrity rights will occur.[45]

The "law of coercive responsiveness" is especially problematic for female leaders when dealing with terrorist threats. A woman chief executive must be both hawkish and hard-lined with the terrorist group, but must remain caring and compassionate towards the population. In other words, we ask women leaders to display both masculine and feminine traits at once, something we do not ask male leaders to do. Again, this sheds light on the political catch-22 faced by women leaders. In terms of dealing with domestic terrorism, it can be difficult to be two things at once when terrorists can hide within that domestic population. 


\section{Journal of Terrorism Research}

In other words, we bind the actions women leaders can take in regards to counterterrorism. Corazon Aquino, for example, gave permission for civilian volunteers to carry out counterinsurgency tactics, and later Amnesty International reported human rights violations by these volunteers. [46] For some, this tarnished the overtly feminine personality that Aquino was known for. Moreover, despite these efforts, the National Democratic Front and the Moros continued terrorist activity. In effect, there is no ideal degree of response that will both satisfy a frightened public and sufficiently neutralize a terrorist organization's capacity to produce violence. This is a defining characteristic of a catch-22 - a difficult situation with no easy solution.

Given the stereotypes that exist portraying women leaders as compassionate and caring, we argue that terrorist groups purposefully target female chief executives as a tool for either recruiting more members, generating more sympathizers, or getting more of their demands met by the regime. The female chief executive is in a bind in how to respond to domestic threats. In effect, women leaders must work harder to win, because if they lose it could be political suicide.[47 However, if a female leader represses her people, as many leaders do in this situation, it is the opposite of what the population expects from her due to gendered stereotypes. It is here that the second half of the catch-22 comes into effect. Walsh and Piazza posit that repression leads to a population that is less likely to work with their government to provide information and can create more sympathizers for the terrorist cause.[48] Additionally, terrorists calibrate their response to target states based off of the degree of severity of a state's counterterrorist strategy.[49] As stated previously by Caprioli and Boyer, some female executives counteract their perceived roles by behaving in a more aggressive manner.[50] In a counterterrorist situation, these instances of over aggression can trigger retaliatory terrorist attacks. Evidence of this can be seen in the assassination of Indira Gandhi by two of her own Sikh bodyguards in retaliation for her ordered assault on the Golden Temple, the Sikhs' holiest shrine.[51] Further, if she appears to lose to the terrorist group this could hurt her political career. In other words, female leaders are in a lose-lose situation when facing terrorist activity. They are in a paradoxical situation of needing to be both masculine and feminine at the same time. It can be nearly impossible to display contradictory qualities in the face of terrorism. This makes them an elevated target for terrorism, leading to our hypothesis.

Hypothesis: Women chief executives will experience more domestic terrorist attacks than men.

\section{Research Design}

\section{Dependent Variable}

Data are taken from a sample of 188 states between the years 1980-2011. The unit of analysis is a countryyear. Data on the frequency of terrorist violence consists of a raw count of domestic terrorist incidents that occur within a country's geographical boundaries and are taken from the Global Terrorism Database, or GTD, collected by the Center for the Study of Terrorism and Responses to Terrorism (START Center) at the University of Maryland.[52] The GTD data conform to our earlier definition of terrorism in that the incident must be intentional, include either the threat or presence of violence, and consist of sub-national actors as the primary perpetrators. To further ensure that we are working exclusively with terrorism incidents divested from other forms of political violence, the attack data consist of successful attacks in which three additional filtering mechanisms are present. Specifically, the act must be conducted in pursuit of a political, economic, religious, or social motive that is intended to coerce or intimidate a broader audience or audiences, which is outside the context of legitimate warfare activities. Additionally, the terrorist incident must be affiliated to a known terrorist organization. This is meant to distinguish attacks carried out by a single individual, a lone 
wolf, from those that are the product of organizations such as Al Qaeda or the Irish Republican Army (IRA). The logic behind lone wolf terrorism can be hypothesized to stem from psychological factors inasmuch as political factors. [53] As a result, only attacks from terrorist organizations are included.

Summary statistics display a conditional mean far lower than the variance across both dependent variables, indicating overdispersion in its distribution across observations. We assume that the counts of attacks within more than one observation are not independent of one another. The main culprit behind this overdispersion is due to the large occurrence of zeroes within many of the observations in which no terrorist attacks occurred within a given year. Because of this assumption and the fact that the dependent variable consists of nonnegative integers, a negative binomial model is used rather than a Poisson or OLS method.[54]

\section{Independent Variables}

The main independent variable of interest concerns gender and leadership in the executive, and consists of a simple dummy variable, Female Chief Executive (FCE), coded as a 1 if female and a 0 otherwise. This is a preliminary look into the effects of gender. The theory behind terrorist violence stems from the perception of the terrorist, which circumvents the conceptual weight that the term "gender" embodies. It is reasonable to assume that the terrorist organizations within our data view gender in a binary fashion or approximate it as such. Additionally, executive leadership is the sole position of analysis due to its visibility with the public. Our theory ties gender and leadership to perceptions from the terrorist organization in addition to public expectations about how a female leader is "supposed" to govern. Given the rich literature on the dearth of political knowledge in the American electorate and the tangential evidence suggesting similar patters in Western Europe, we assume that the gender of subordinate leadership positions is something that the public is either unaware of or unconcerned with.[55] Data on the dispersion of FCEs by length of tenure in years are presented in map format in Figure 1. Darker shades indicate a longer length of tenure. The average length of an FCE is 5.31 years in office, with a standard deviation of 4.62. The minimum term is one year, which is characteristic of a sizeable minority of states with FCEs, and the maximum is 19, which was held largely via the alternations of female political rivals Sheikh Hasina and Khaleda for the position of the Prime Minister of Bangladesh. Cursory analysis of the map reveals that FCEs are not particularly concentrated in any one region of the globe, nor are they confined to any particular regime type. In addition to Bangladesh, countries that have had FCEs for the longest tenure include Norway, Finland, the UK, Philippines, and New Zealand. There are also a substantial number of states in South America and Southeast Asia that have had female leaders at one time or another. The most obvious piece of information conveyed by this figure, however, is the number countries that do not have a female leader in our data. This underrepresentation, compounded with the broad dispersion of female leaders and our very strict interpretation of terrorist events, provides a hard test for the effects of gender stereotyping on the part of terrorist organizations. 


\section{Journal of Terrorism Research}

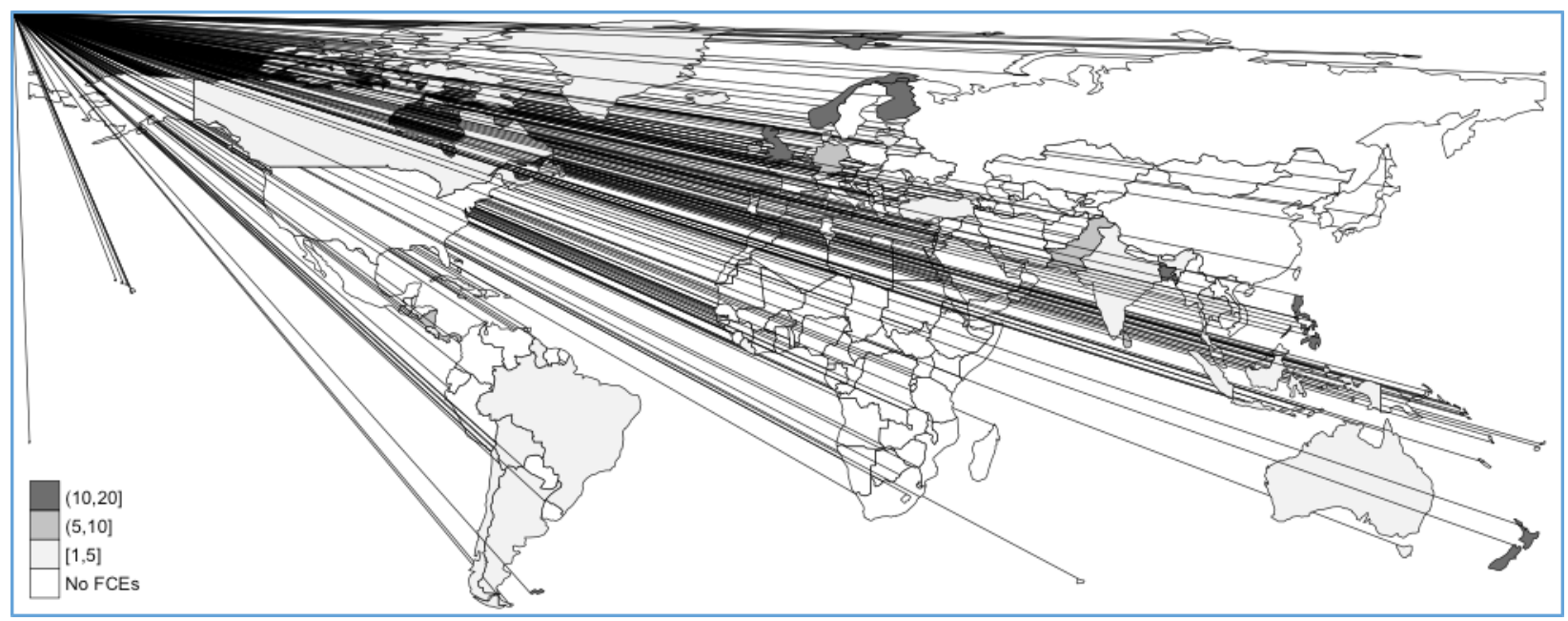

Figure 1. Map of FCEs by Term Length (years)

While both male and female leaders may be products of political dynasties or political appointments, many female leaders are chosen to serve as an interim leader to fill a void or achieve their status based off of a familial or marital relationship to a powerful male politician. [56] Furthermore, there is a consensus indicating that women who ascend to politically powerful offices are more likely to recruit women to positions of authority and are more likely to network with other women.[57] These relationships could work to mitigate the occurrence of political violence and terrorism overall, as empirical research shows that violent conflict is less likely in countries with empowered women.[58] To account for this and isolate the gender of the executive exclusively, we control for women's empowerment. This variable is an index taken from the Varieties of Democracy (V-Dem) project, housed at the University of Gothenburg. [59] Utilizing nine democratic indicators, the index ranges from 0 to 1 , with 1 signaling complete empowerment along three political dimensions: political choice, women civil liberties, and women civil society participation. It is expected to have a negative relationship with the occurrence of terrorist violence.

The remaining independent variables attempt to set up a standard model for conditions that are favorable to the occurrence of terrorism and largely follow a model put forth by Qvortrup and Lijphart.[60] Additional controls are then added as a robustness check. The base controls intend to capture both institutional and sociological factors that create a favorable environment for terrorist activity. In effect, these variables intend to model the expected value of engaging in terrorism against the expected value of not engaging in terrorism and include some of the most frequently used explanatory variables for domestic terrorism. According to the theory outlined previously, the presence of female leadership in the executive conveys to terrorist groups that leadership is weak, and that terrorist violence will be a more effective method of conveying political change than conventional channels. Hence, female leadership increases the expected payoff of utilizing terrorism by lowering the costs of engaging in terrorist activity.

The first set of variables captures institutional features. Terrorism utilizes strategic violence against civilian targets as a political message. These distinctive features make it extremely reactive to regime type.[61] To this end, a Polity IV measure is included to capture the effects of democracy.[62] The effects of democracy in the terrorist literature can be divided into two strands of thought, each balanced upon the institutional guarantees that protect the freedom of association and expression, the assurance of free and fair elections, and the rights of citizens to participate in the electoral process as first conceptualized by Dahl.[63] Depending on the viewpoint, these protections are either a method of exploitation for terrorists, allowing 


\section{Journal of Terrorism Research}

them the logistical ease to carry out their violent activities, [64] or conversely they function as an escape valve that provides a method for disenfranchised groups to eschew violence in favor of a method that allows them to peacefully air their grievances.[65]

To more precisely capture the political grievances inherent within a given state as well as the government response, two measures of repression are included. The data are taken from Cingranelli and Richards and consist of two indexes. [66] The first measures physical integrity rights and consists of an index of torture, extrajudicial killing, political imprisonment, and disappearance indicators. The second measures political empowerment and is constructed from freedom of movement, freedom of speech, workers' rights, political participation, and freedom of religion indicators in the data set. On both measures, a positive increase on the value indicates an increase in respect of rights. The logic behind the relationship between terrorism and repression is best captured through the security-liberty tradeoff. Consistent with the argument that democracies increase terrorist incidents, states with low levels of repression make especially appealing targets, because terrorists are able to exploit human rights freedoms through asymmetric tactics. This is due to their inability to defeat their enemy in the more traditional sense.[67] In effect, the game between freedom and security is zero-sum. Indeed, this tradeoff is sharper with regards to terrorism than other threats such as international war, where an enemy is an identifiable state actor.[68] However, moving to the other side of the scale by increasingly restricting rights may also drive the frequency of terrorist violence in the positive direction. The rationale within this conclusion is well defined in research on counterinsurgency, where winning the "hearts and minds" of a local population circumspect of, yet not outright opposed to, terrorist organizations is the strategic goal in order to thin the enemy's ranks. [69] This logic can be extended to terrorism,[70] and can partially explain the Obama administration's revocation of the phrase, "Global War on Terror." To further refine the effects of violence on terrorism, a civil war dummy is included that indicates whether a country experienced an intrastate conflict of at least 25 battle deaths within a given year, per the Peace Research Institute Oslo data.[71] Since terrorism is an oft-employed tactic in civil wars, it is expected that the presence of a civil war will increase the occurrence of terrorist violence. Although great effort was made to parse terrorist acts carried out in pursuit of civil war related goals from of the data, this variable will serve as an additional robustness check.

The remaining controls intend to measure the sociological aspects that drive terrorist behavior. Youth bulge consists of the percentage of the population between the ages of 10 and 25 years of age. The argument is that states with exceptionally large youth cohorts are more prone to terrorism.[72] The second control, urbanization, measures the proportion of the population living in an urban area. Urbanization trends towards aggregation and complexity, which increases the wealth and accessibility of targets for terrorists. [73] Human development index (HDI) captures the latent frustration that exists between the mixes of highly developed and less developed cohorts that could lead to acts of terrorism. [74] GDP is the log of a state's gross domestic product per capita and is taken from The World Bank, World Development Indicators. [75] GDP is a widely used variable in the literature that presents mixed effects. Some studies show a negative relationship with terrorism, [76] while others finds a null relationship.[77] Poverty is a reasonable grievance that could motivate terrorism, however, it is also equally possible that financial issues would not be a primary concern for ideological or religious organizations. [78] Since we make no attempt to measure terrorist ideology, we are unsure of its impact and direction of influence. A logged population is included, as it is suggested that countries with large populations suffer from a greater frequency of terrorist attacks. [79] Finally, to control for geographic and cultural characteristics, regional dummies are included. Summary statistics are presented in Table 1. 


\section{Journal of Terrorism Research}

Table 1: Summary Statistics

\begin{tabular}{lccccc}
\hline Variable & Obs. & Mean & Std. Dev. & Min & Max \\
\hline Attacks & 5460 & 4.474 & 27.122 & 0 & 544 \\
Major Attacks & 5753 & 0.232 & 2.166 & 0 & 84 \\
Casualties & 5460 & 10.262 & 65.888 & 0 & 1953 \\
Female Chief Executive & 5353 & 0.033 & 0.178 & 0 & 1 \\
GDP per capita, ln & 4832 & 7.857 & 1.581 & 4.597 & 12.174 \\
Youth Bulge, ln & 4746 & 7.459 & 1.863 & 2.847 & 12.790 \\
HDI & 2031 & 40.815 & 9.981 & 16.23 & 99.91 \\
Population, ln & 4902 & 15.536 & 2.006 & 10.161 & 21.014 \\
Urbanization, ln & 4905 & 51.960 & 23.831 & 4.339 & 100 \\
Polity & 4290 & 1.932 & 7.368 & -10 & 10 \\
Electoral Parties & 2455 & 4.778 & 5.065 & 1.23 & 57.56 \\
Parliamentary Parties & 2455 & 3.831 & 8.243 & 1 & 178 \\
Women's Empowerment & 4095 & 0.649 & 0.202 & 0.110 & 0.969 \\
Physical Integrity & 3579 & 5.029 & 2.303 & 0 & 8 \\
Empowerment Rights & 3579 & 6.013 & 3.257 & 0 & 10 \\
Civil War & 5656 & 0.128 & 0.334 & 0 & 1 \\
\hline
\end{tabular}

\section{Results}

The first analyses looks at whether female executives are more likely to experience terrorism in general. To do this, the raw count data is recoded as a binary variable to record whether any acts of terrorism take place within a country year. The results take the form of a simple joint frequency distribution and are presented in Table 2. The results show a distinctive pattern. Despite only representing 3.3\% of the observations, FCEs experience 7\% of the incidents of terrorist violence. As Table 1 displays, the odds of a female leader experiencing a terrorist attack within a given year are approximately $60 \%$, compared to their male counterparts at $21 \%$. This gives us an odds ratio of $.60 / .21=2.89$, indicating that female leaders have a 2.9 greater odds of experiencing terrorist attacks in a given year. These results show early support for the hypothesized relationship.

Table 2. Odds of the Presence of Terrorist Violence Within a Country-Year Male Chief Executive

Female Chief Executive

\begin{tabular}{lcc}
\hline Absence of Violence & 4436 & 119 \\
Presence of Violence & 919 & 71 \\
Odds of Terrorist Violence & 0.21 & 0.60 \\
\hline
\end{tabular}

Odds Ratio $=2.879 ; X^{2}=51.085 ; p<.001$

To test the main hypotheses of whether female leaders experience terrorist attacks in greater frequency in a 


\section{Journal of Terrorism Research}

more rigorous manner, we turn to our full models employing negative binomial regression. We are interested in the effects of variables across observations as well as over time, particularly the gender of executive leadership. Because fixed effects estimation eliminates spatial variation of fixed characteristics such as gender, a random effects model is estimated.[80] In addition to a lagged dependent variable to control for temporal dependence, all time-dependent variables on the right side are lagged. Across all of the models tested, the likelihood-ratio chi-square test of the dispersion parameter is significantly different from zero, indicating that the dependent variables are over-dispersed and not sufficiently described by Poisson estimation.

The results are displayed in the Table 3 and examine the relationship between female leadership and the frequency of domestic terrorist attacks. The coefficients presented are incidence rate ratios. Since the difference in logs is equal to the log of their quotient, and we can technically interpret a count as a rate, we can remodel the regression coefficients as the log of the rate ratio. A coefficient greater than 1 indicates an increase in the frequency of terrorist attacks. Model 1 presents the baseline effects, and we can clearly see that the presence of a female chief executive increases the frequency of terrorist attacks as compared to her male counterparts. This relationship is confirmed true below a 0.05 probability of error, reporting that FCEs experience almost $40 \%$ more attacks than their male counterparts. HDI is the sole sociological variable that garners a significant effect, indicating that as the gap on development closes, there is a rise in terrorist violence by $2 \%$ with every unit increase. This is a curious finding, as it suggests that physical grievances alone are an insufficient motivator for terrorism. Significance is also observed in the Latin American and East Asian regional controls, with each experiencing almost 67\% more terrorist attacks than the rest of the world.

The second model increases our understanding of the driving factors behind domestic terrorism considerably. Female chief executives still experience $42 \%$ more attacks than their male counterparts, despite the inclusion of repression controls. These three variables depict contradictory effects. Concerning the treatment of women, countries that have large numbers of empowered women experience a lower frequency of terrorist attacks by a significant margin. Indeed, increasing Women's Empowerment by a standard deviation leads to an $18.5 \%$ reduction in terrorist violence. It was hypothesized a state's repression of women may drive both the occurrence of terrorism and whether there is a female leader, thus presenting a spurious

link between gender perceptions and terrorism. This control highlights that, regardless of the gender equality of a state or the manner in which a female executive achieved her status, female chief executives experience a greater frequency of terrorist attacks. The gender of the chief executive influences terrorist attacks independently of female empowerment. Hence, the gender relationship comes into even starker contrast when controlling for repression.

The two indexes of political and physical repression also reveal an interesting relationship. States with higher levels of political empowerment experience an increase in terrorist attacks, while respect for physical integrity results in a decrease in attacks. This relationship suggests that terrorists do indeed exploit the civil liberties that free states bestow upon their population, including freedom of speech, association, and religion. This suggests that the political "carrots" that democracies offer to their public comes with unintended costs. However, the "sticks" that states employ to counteract terrorism, such as killings, torture, and imprisonment sow the seeds of discontent that alienates the population from the government and makes it more difficult for the government to collect intelligence and appropriately monitor suspect groups. [81] Such a response undermines effective counterterrorist policies. It is also worth noting that measure of democracy reflected in the Polity IV measure becomes positive and significant when controlling for repression, which is in line with much of the literature that indicates a positive relationship between the level of democracy and the occurrence of domestic terrorism. 


\section{Journal of Terrorism Research}

Finally, the full model includes the occurrence of civil wars. Looking at female leadership first, a coefficient of 1.35 is presented in model three. This indicates that the presence of a female chief executive results in a $35 \%$ increase in the frequency of terrorist attacks. When examining Women's Empowerment, we see consistent results from model 2 . The effects of repression are revealed in the last column as well. Every unit increase on the 8-point scale of physical integrity, indicating respect for civilian rights, reduces the frequency of attacks by $10 \%$ while an increase on the 10 -point scale of empowerment increases the frequency by $6.8 \%$. These findings largely confirm Wilson and Piazza's (2013) study of political institutions. Their study splits institutions into military autocracies, single-party authoritarian regimes, and democracies. Out of the three regimes, single-party authoritarian regimes experience the fewest number of attacks. This is attributed to the regime's ability to achieve the correct mix of counterterrorism policies, including the "carrots" of political inclusiveness offered by democracies, with the "sticks" of physical punishment that are present largely in militaristic dictatorships 


\section{Journal of Terrorism Research}

Table 3. Negative Binomial Regression: Chief Executive Gender and Domestic Terrorism Incidents, 1980 $-2011$

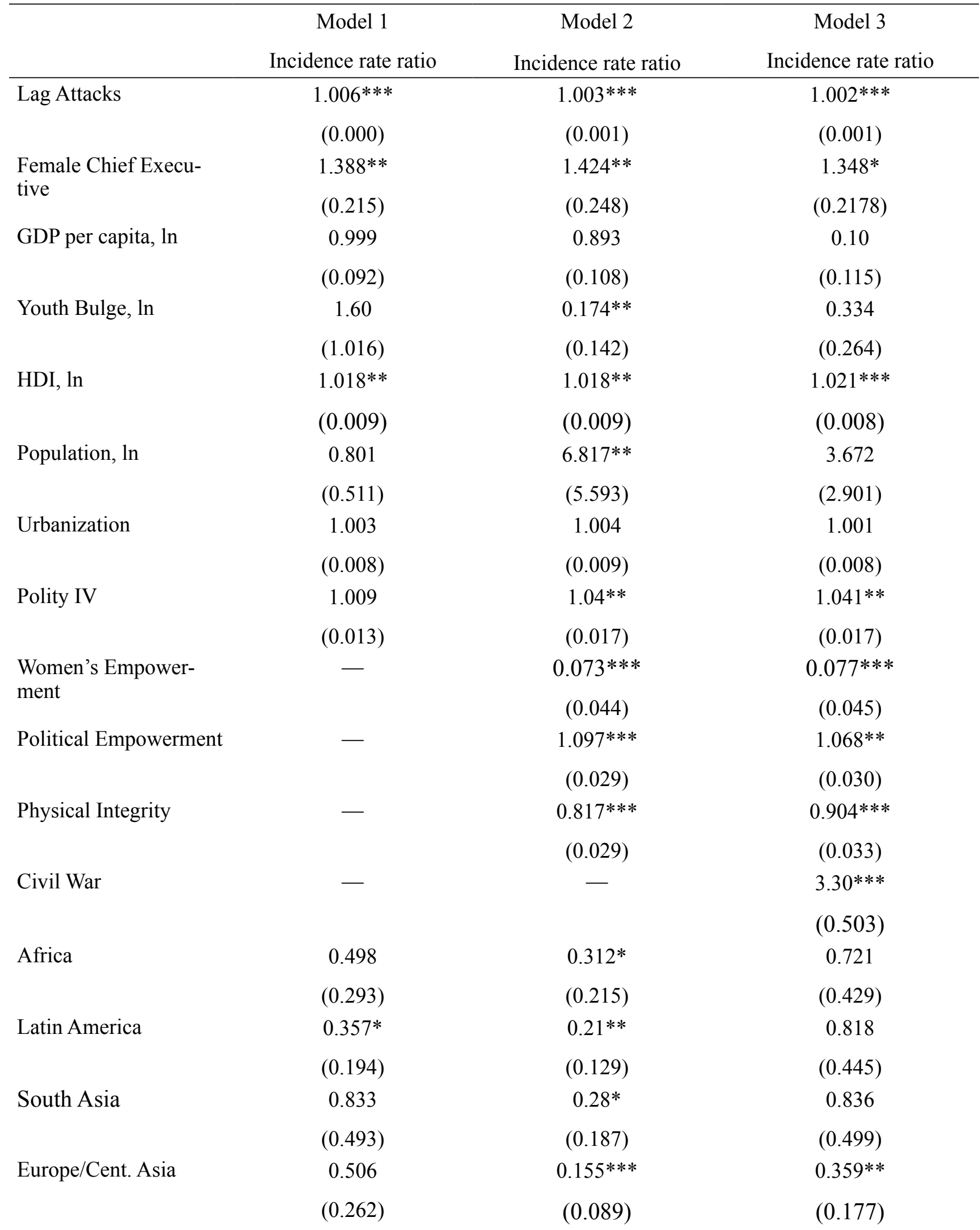




\section{Journal of Terrorism Research}

\section{Middle East}

1.358

$(0.878)$

$0.334 * *$

$(0.186)$

0.144

Constant

Wald $X^{2}$

$303.79 * * *$

Probability $>X^{2}$

0.000

1919
0.697

$0.201 * * *$

$(0.126)$

$0.000 * *$

$(0.000)$

$236.05 * * *$

0.000

1461
1.053

$0.000 * *$

$308.33^{* * *}$

0.000

1461

Standard errors in Parentheses $p<.01^{* * *} ; p<.05^{* *} ; p<.10^{*}$

Overall, the results across all three models of terrorist violence suggest that gender stereotyping is a global phenomenon that even reaches into relatively progressive states, and that female leaders in highly visible leadership positions can trigger terrorist violence regardless of policy preference or executive decisionmaking.

\section{Robustness Checks}

Given the low representation of female leadership throughout history, we previously argued that females are pressured to emasculate to a higher degree in order to convince the public that they are worthy of handling traditionally "male" centric endeavors such as conflict and international politics. To this end, Fukuyama suggests that female leaders are actually more violent than men, noting the trials of Indira Gandhi against Sikh separatists in India and her war with Pakistan, Golda Meir's hard line against the Arab world and Palestine, and Margaret Thatcher's role in the Falkland War and, more pertinent to this study, the Irish Republican Army.[82] In particular, it is speculated that Thatcher exclusively could be a driver in the gender variable due to her heavy handed policies against the IRA, which could generate a backlash of terrorist attacks sufficient to bias the small sample of female leaders. To test this, a second model is run with the Cold War dummy variable coded as a " 1 " for the years 1980 to 1991 . The coefficients result in a minor drop in the significance and magnitude, yet the overall model shows no deviation worth note. To directly test for the "Thatcher Effect" the results were run again without the observations in which Thatcher was Prime Minister. Again, there is no significant deviation, upholding the robustness of the gender variable.

A corollary to the argument that female executives employ harsher repressive tactics concerns the direction of causality. It is posited here that terrorists perceive female leaders as weaker adversaries to their male counterparts. Figuring that the retaliation from the executive will be minimal, or that the public will chastise a female leader as ineffective at providing domestic security, terrorist organizations calculate, either implicitly or explicitly, that the costs of terrorism are lowered when a female executive is in office. However, consistent with Fukuyama, it could be that female leaders actually are more repressive.[83] As the results show, increasing repression of physical rights leads to an increase of terrorist violence. Additionally, there is a significant strand of literature arguing that increased repression leads to a series of retaliatory attacks, much like the relationship present in counterinsurgencies.[84] If female executives are more likely to employ physical repression, it calls into question the direction of causality. Preliminary evidence shows mixed support. A two-sample t-test shows that female executives are less likely to respect physical integrity rights, with a sample mean difference of -0.55 significant at .01 (Female: 4.49 - Male: 5.04), but 


\section{Journal of Terrorism Research}

they are simultaneously more likely to uphold political empowerment rights (Female: 7.57 - Male: 5.96), with a sample mean difference of 1.61 significant at .01. A tentative argument could theorize that women are generally more inclusive towards marginalized groups, since they are traditionally a minority group themselves. This inclusion represents the softer, "feminine" aspect of their leadership. However, compared to their male counterparts, they uphold their authority with an iron fist and are quick to crush dissent, a representation of their obligation to behave "masculine" when the time calls for it. More research is needed to explain this dynamic. Regardless, to test for the direction of causality, ordered logit regressions are run on each repression variable. The results show that repression is partially a function of past attacks, but that the gender of the executive plays no role in the reaction. Since the dependent variables have a fairly wide range, the models are run again with OLS. The coefficients show minimal change and gender remains insignificant. This implies that the causality runs in the hypothesized direction.

\section{Conclusions and Future Research}

This study is one of the first of its kind to examine the relationship between women leadership in government and terrorist behavior. Utilizing existing arguments on gender stereotypes and perceptions, we extend the theoretical logic that portrays women as violence averse into a terrorist organization's cost-benefit evaluations when deciding when and how to resort to terrorism. The results both confirm and extend existing theory, finding that the perceptions of gender lower the costs of engaging in terrorist activity. Additionally, the perceived and real aggressiveness of counterterrorist strategies are magnified when conducted by a female executive, which can trigger a backlash of violence. Regardless of the mechanism, the result is the same: female leaders experience terrorist attacks with greater frequency. Consistency across all three of our models depicts a relationship that is more than an mere artifact and is something that terrorists work into their decision calculus, even if inadvertently. Though this is one of the few studies to directly look at the relationship between women and terrorism in this manner, the results should not come as a surprise. Despite the massive amount of variance among countries with regard to their treatment of women, the fact of the matter remains that there have been very few women in positions of executive leadership, revealing a reluctance of even the most progressive states to bestow such grand, far-reaching, physical and symbolic power that chief executives so often embody into the hands of a woman. Terrorist organizations comprise groups of politically and socially marginalized individuals who eschew political compromise in favor of coercive violence to achieve goals that are not in line with mainstream thought. Yet in terms of gender stereotyping, it appears that large swaths of the global public align with terrorist logic on the thought of female leadership in the seat of national security.

This research question is still in its infancy. It is unclear which side of the catch-22 drives the response variable and when. However, the robust effects of gender demonstrate that there is indeed a relationship between women leaders and domestic terrorist activity, which is strengthened further when one considers that women leaders make up less than $4 \%$ of our observations. Furthermore, female leadership is dispersed across the globe and is not regionally concentrated in any one area, which controls for specific cultural perceptions. Indeed, it appears that this is a global phenomenon, independent of any one region. Further research can more directly measure this relationship by examining the actual attitudes towards women leaders by examining the media that terrorist organizations produce. Many organizations publicize their motives in manifestos, websites, videotapes, and interviews. [85] Such material produces a wealth of knowledge into guiding philosophies and worldviews of terrorist organizations. Content analyses of news 


\section{Journal of Terrorism Research}

media affirm that women are portrayed as out of place when participating in male domains such as national security and terrorism.[86] When examining the narratives of women in the war on terror, women are not perceived as legitimate actors with a sense of agency. This framing is evident even in countries in which women enjoy a relative status of equality with men.[87] As can be seen here, such a system of framing can affect actual matters of national security. Learning how these frames alter terrorist perceptions would further our understanding of gender and could quite possibly lead to methods that subtly increase both domestic and international security in ways heretofore unseen.

Another factor overlooked in this study is the ideology of the terrorist group. It is highly possible that rightwing, reactionary terrorist organizations would be more likely to oppose an executive solely on the basis of gender due to pre-established and deeply held beliefs about the social hierarchy. While it true that women join both left and right-wing terrorist organizations, including deeply conservative organizations like the Islamic State, their roles in right-wing organizations tend to be downplayed and subordinate in contrast to liberal organizations, which see greater female involvement in both proportion and leadership positions. [88] The results here treat terrorism as a monolith, its existence portrayed as a function of institutional and demographic characteristics of the state, in addition to the gender of the executive. It should be examined whether specific state characteristics, including the gender of chief executives, elicit similar or different reactions from terrorist organizations across the ideological spectrum. The significance of this study and future endeavors down this path of research are manifest and suggest that, all things being equal, a female leader will face unique challenges to ensuring domestic security that a male counterpart of the exact character and political ideology would not.

\section{Notes}

[1] Courtney R. Conrad, Justin Conrad, and Joseph Young, "Tyrants and Terrorism: Why Some Autocrats are Terrorized While Others are Not,” International Studies Quarterly 58 (2014): 539-549.

[2] James I. Walsh, and James A. Piazza, "Why Respecting Physical Integrity Rights Reduces Terrorism," Comparative Political Studies 43, no. 5 (2010): 551-557; Ursula E. Daxecker, and Michael L. Hess, "Repression Hurts: Coercive Government Responses and the Demise of Terrorist Campaigns," British Journal of Political Science (January 2013): 1-19.

[3] Koch and Fulton (see note 1 above).

[4] Farida Jalalzai, "Women Political Leaders: Past and Present," Women and Politics 26, no. 3/4 (2004): 85108.

[5] Adam Winkler, “Heller’s Catch-22”, UCLA Law Review 56 (2009, 1552).

[6] Ceilia Ridgeway, “Gender, Status, and Leadership," Journal of Social Issues 57 (2001): 637-655

[7] Michael Koch and Sarah Fulton, "In Defense of Women: Gender, Office Holding, and National Security Policy in Established Democracies," Journal of Politics 73, no. 1 (2011): 1-16. 


\section{Journal of Terrorism Research}

[8] We acknowledge that gender and sex are not the same thing. We are in line with the argument that gender is a social construct displayed by people based on their biological sex and that biological sex does not necessarily define one's gender (Steans 1998). While sex and gender do not coincide with one another naturally, there are societal expectations that if one is a man one will be masculine and if one is a woman one will be feminine. This concept makes the study of gender in International Relations particularly murky, especially quantitatively. For example, not every leader in the world has explicitly stated their biological sex and their gender identification. However, we believe that understanding leadership traits is important to the study of terrorism and International Relations. In order to further this study, we must make some large assumptions about gender and sex. By no means do we employ a perfect measure of gender, but to the best of our ability we have found that biological women leaders are female and biological men leaders are male. In our research, then, we equate woman with female and man with male. Furthermore, our research will highlight some of the problems that gender and gender assumptions have for leaders. For more information, see Jill Steans, Gender and International Relations (New Brusnwick, NJ: Rutgers University Press, 1998).

[9] Jennifer L. Merolla and Elizabeth J. Zechmeister, “Terrorist Threats, Leadership, and the Vote: Evidence from Three Experiments," Political Behavior 31 (2009): 575-601.

[10] Inge K. Broverman, S. R. Vogel, D. M. Broverman, F. E. Clarkson, and P. S. Rosenkrantz, "Sex-Role Stereotypes: A Current Appraisal," Journal of Social Issues 28 (1972): 59-78; Irene Diamond, Sex Roles in the State House (New Haven, CT: Yale University Press, 1977); Ruth B. Mandel, In The Running: The New Woman Candidate (New Haven, CT: Tichnor \& Fields, 1981); Raisa Deber, “'The Fault, Dear Brutus': Women as Congressional Candidates in Pennsylvania," Journal of Politics 44 (1982): 463-79; Virginia Sapiro, The Political Integration of Women: Roles, Socialization, and Politics (Urbana, IL: University of Illinois Press, 1983).

[11] Deborah Alexander and Kristi Andersen, "Gender as a Factor in the Attribution of Leadership Traits," Political Research Quarterly 46 (1993): 527-45.

[12] Lise Togeby, “The Gender Gap in Foreign Policy Attitudes,” Journal of Peace Research 31 (1994): 375-92; Clyde Wilcox, Lara Hewitt, and Dee Allisop, "The Gender Gap in Attitudes Toward the Gulf War: A CrossNational Perspective," Journal of Peace Research 33, no. 1 (1996): 67-82;

[13] Juliana Menasce Horowitz, "Global Opinion of Obama Slips, International Policies Faulted: Drone Strikes Widely Opposed," Pew Research Global Attitudes Project, (June 13, 2012): http://www.pewglobal. org/2012/06/13/global-opinion-of-obama-slips-international-policies-faulted/, accessed on August 23, 2016.

[14] Wilcox, Hewitt, and Allison (see note 7 above).

[15] Alice H. Eagly. "The Science and Politics of Comparing Women and Men," American Psychologist 50, (1995): 145-161.

[16] Catherine C. Eckel and Phillip J. Grossman. "Are Women Less Selfish than Men? Evidence from Dictator Experiments," Economic Journal 108 (1998): 726-735.

[17] Koch and Fulton (see note 1 above).

[18] Nancy E. McGlen and Meredith Reid Sarkees, Women in Foreign Policy (New York, NY: Routledge, 1993).

[19] Miki C. Kittilson, "Representing Women: The Adoption of Family Leave in Comparative Persepctive," Journal of Politics 70, no. 2 (2008): 323-334; Amy Atchinson and Ian Down, "Women Cabinet Ministers and Female-Friendly Social Policy," Poverty and Public Policy 1, no. 2 (July 2009): 1-23. 


\section{Journal of Terrorism Research}

[20] Mary Caprioli, "Primed for Violence: The Role of Gender Inequality in Predicting Internal Conflict," International Studies Quarterly 49 (2005): 161-178.

[21] Nichole M Bauer, "Emotional, Sensitive, and Unfit for Office? Gender Stereotype Activation and Support Female Candidates," Political Psychology 36, no. 6 (2015): 691-708. Jennifer Lawless, "Women, War, and Winning Elections: Gender Stereotyping in the Post-September $11^{\text {th }}$ Era," Political Research Quarterly 57 (2004): 479-490. Mirya R. Holman, Jennifer L. Merolla, and Elizabeth J. Zechmeister, “Terrorist Threat, Male Stereotypes, and Candidate Evaluations," Political Research Quarterly 69 no 1 (2016): 134-147.

[22] Mirya R. Holman, Jennifer L. Merolla, and Elizabeth J. Zechmeister, “Terrorist Threat, Male Stereotypes, and Candidate Evaluations," Political Research Quarterly 69 no 1 (2016): 134-147.

[23] Russell J. Dalton, Yun-han Chu, and Doh Chull Shin, "Introduction: Parties, Party Choice, and Partisanship in East Asia," Journal of East Asian Studies 7 (2007): 177-184.

[24] Thomassen, Jacques, "Party Identification as a Cross-National Concept: Its Meaning in the Netherlands," in Party Identification and Beyond, edited by Ian Budge, Ivor Crewe, and Dennis Farlie, (London: Wiley, 1976).

[25] Erika Falk and Kate Krenski, "Issue Saliency and Gender Stereotypes: Support for Women as Presidents in Times of War and Terrorism," Social Science Quarterly 87 no. 1 (2006): 1-18.

[26] Pamela Paxton and Melanie Hughes, Women, Politics, and Power: A Global Perspective, (CA: Sage, 2014).

[27] Alice H. Eagly, M. G. Makhijani, and B. G. Klonsky, "Gender and the Evaluation of Leaders: A MetaAnalysis," Psychological Bulletin 111 (1992): 3-22.

[28] Ceilia Ridgeway, “Gender, Status, and Leadership,” Journal of Social Issues 57 (2001): 637-655.

[29] Julie Dolan, Melissa Deckman, and Michele L. Swers, Women and Politics: Paths to Power and Political Influence, (NJ: Pearson, 2007).

[30] Leonie Huddy, and Nadya Terkidlsen, "Gender Stereotypes and the Perception of Male and Female Candidates," American Journal of Political Science 37, no. 1 (1993): 119-147.

[31] Ibid.

[32] Caprioli and Boyer 2001 (see note 1 above), 507.

[33] Pamela Paxton and Melanie M. Hughes, Women, Politics, and Power: A Global Perspective, Third Edition, (CQ Press, 2016).

[34] Jalalzai 2004 (see note 5 above).

[35] Ibid.

[36] Ibid.

[37] Walter Enders and Todd Sandler, The Political Economy of Terrorism, (New York: Cambridge University Press 2006, 3).

[38] David A. Lake, "Rational Extremism: Understanding Terrorism in the Twenty-First Century," International Organization (Spring 2002): 15-29; Joseph K. Young and Michael G. Findley, "Promise and Pitfalls of Terrorism Research," International Studies Review 13, no. 3 (September 2011): 411-431.

[39] Matt Ovortrup and Arend Lijphart, "Domestic Terrorism and Democratic Regime Types," Civil Wars 15, no. 4 (2013): 471-485. 


\section{Journal of Terrorism Research}

[40] Harvey E. Lapan and Todd Sandler, “Terrorism and Signaling," European Journal of Political Economy 9, no. 3 (1993): 383-97; Ethan Bueno de Mesquita, "Conciliation, Counterterrorism, and Patterns of Terrorist Violence," International Organization 59, no. 1 (2005): 145-76; Navin Bapat, "State Bargaining with Transnational Terrorist Groups,” International Studies Quarterly 50, no. 1 (2006): 213-29.

[41] Enders and Sandler (see note 24 above).

[42] Ibid.

[43] James I. Walsh and James A. Piazza, "Why respecting Physical Integrity Rights Reduces Terrorism," Comparative Political Studies 43, no. 5 (2010): 551-557; Daxecker and Hess (see note 3 above).

[44] Peter B. Rosendorff and Todd Sandler, “Too Much of a Good Thing?: The Proactive Response Dilemma," Journal of Conflict Resolution 48, no. 5 (2004): 657-671; Peter B. Rosendorff and Todd Sandler, "Suicide Terrorism and the Backlash Effect," Defense and Peace Economics 21, no. 5-6 (2010): 443-457.

[45] Christian Davenport, "State repression and Political Order," Annual Review of Political Science 10 (2007): 1-23; Steven Poe and C. Neal Tate, "Repression and Human Rights to Personal Integrity in the 1980s: A Global Analysis," American Political Science Review 88, no. 4 (1994): 853-872; Courtenay Rvals Conrad and Will H. Moore, "What Stops the Torture?" American Journal of Political Science 54, no. 2 (2010): 459-476.

[46] Carolina G. Hernandez, "the Philippines in 1987: Challenges of Redemocratization," Asian Survey 28, no. 2 (1988): 229-241.

[47] Caprioli and Boyer 2001 (see note 1 above).

[48] Walsh and Piazza 2010 (see note 3 above).

[49] Rosendorff and Sandler 2004 (see note 30 above).

[50] Caprioli and Boyer (see note 1 above).

[51] Clutterbuck, Richard. Terrorism and Guerrilla Warfare: Forecasts and Remedies (New York: Routledge, 1993).

[52] Khusrav Gaibulloev, Todd Sandler and Donggyu Sul, "Common Drivers of Transnational Terrorism: Principal Component Analysis," Economic Inquiry 51, no. 1 (2013): 707-721; National Consortium for the Study of Terrorism and Responses to Terrorism (START, 2011).

[53] R. Spaaij, “The Enigma of Lone Wolf Terrorism: An Assessment,” Studies in Conflict and Terrorism 33, no. 9 (2010): 854-70.

[54] Patrick T. Brandt, John T. Williams, Benjamin O. Fordham, and Brian Pollins, "Dynamic Models for Persistent Event Count Time Series," American Journal of Political Science 44, no. 4 (2000): 823-843; Gary King, "Statistical Models for Political Science Event Counts: Bias in Conventional Procedures and Evidence for the Exponential Poisson Regression Model," American Journal of Political Science 32, no 3. (1988): 838863; Colin A. Cameron and Pravin K. Trivedi, Regression Analysis of Count Data (Cabridge: Cambridge University Press, 1998). 


\section{Journal of Terrorism Research}

[55] Robert C. Luskin, “Measuring Political Sophistication," American Journal of Political Science 31, no. 4 (1987): 856-899; Russell W. Neuman, The Paradox of Mass Politics: Knowledge and Opinion in the American Electorate (Cambridge, MA: Harvard University Press, 1986); Philip E. Converse, "The Nature of Belief Systems in Mass Publics," in D.E. Apter (eds.) Ideology and Discontent (New York: Free Press, 1964), 206-61; Jason Ross Arnold, “The Electoral Consequences of Voter Ignorance," Electoral Studies 31, no. 4 (2012): 796815; Hobolt, Sara B., “Taking Cues on Europe? Voter Competence and Party Endorsements in Referendums on European Integration," Europe Journal of Political Research 46, no. 2 (2007): 151-82. Models run including the gender of Defense Ministers and Foreign Policy Ministers yielded insignificant results. Given that we have no strong theoretical reasoning for their effect, they are not included in the final results.

[56] Louise K. Davidson-Scmich, "Gender, Intersectionality, and the Executive Branch: The Case of Angela Merkel," German Politics 20, no. 3 (2011): 325-341.

[57] Azza Karam and Joni Lovenduski, "Women in Parliament Making a Difference," in Julie Ballington and Azza Karam (eds.) Women in Parliament: Beyond Numbers (Stockholm: IDEA, 2005).

[58] Caprioli and Boyer 2001 (see note 1 above).

[59] V-Dem Data: Varieties of Democracy. University of Gothenburg. https://www.v-dem.net/en/data/dataversion-6-1/ (last accessed August 25, 2016).

[60] Ovortrup and Lijphart (see note 23 above).

[61] Matthew C. Wilson and James A. Piazza, "Autocracies and Terrorism: Conditioning Effects of Authoritarian Regime Type on Terrorist Attacks," American Journal of Political Science 57, no. 4 (2013): 941955.

[62] Monty G. Marshall and Keith Jaggers, "Polity IV Project: Political Regime Characteristics and Transitions, 1800-2013" Center for Systemic Peace, http://www.systemicpeace.org/polity/polity4.htm (last accessed August 24, 2016).

[63] Dahl, Robert A. Polyarchy: Participation and Opposition (New Haven, CT: Yale University Press, 1971).

[64] Jeffrey Ian Ross, "Structural Causes of Oppositional Political Terrorism: Towards a Causal Model," Journal of Peace Research 30, no. 3 (1993): 317-29; Joe Eyerman, “Terrorism and Democratic States: Soft Targets or Accessible Systems," International Interactions 24, no. 2 (1998): 151-70; Max Abrahms, "Why Democracies Make Superior Counterterrorists," Security Studies 16, no. 2 (2007): 223-53; Kyle T. Kattelman, “Testing the Prisoners' Dilemma of Counterterrorism: An Aggregate Analysis of Counterterrorist Efforts from 2001 to 2010," Journal of International Relations and Development (2014): doi:10.1057/jird.2014.26.

[65] Burcu Savun and Brian J. Phillips, “Democracy, Foreign Policy, and Terrorism," Journal of Conflict Resolution 53, no. 6 (2009): 878-904; Quan Li, "Does Democracy Promote or Reduce Transnational Terrorist Incidents?” Journal of Conflict Resolution 49, no. 2 (2005): 278-97.

[66] David L. Cingranelli and David L. Richards, The Cingranelli-Richards (CIRI) Human Rights Dataset http://www.humanrightsdata.com/ (last accessed June 17, 2016).

[67] Eric A. Posner and Adrian Vermeule, Terror in the Balance: Security, Liberty, and the Courts (New York, NY: Oxford University Press, 2007); Enders and Sandler (see note 24 above); Grant Wardlaw, "Terrorism, Counter-Terrorism, and the Democratic Society," in Government Violence and Repression: An Agenda for Research, (eds.) Michael Stoh and George Lopez (Westport, CT: Greenwood, 1986). 


\section{Journal of Terrorism Research}

[68] James I Walsh, and James A. Piazza, “Transnational Terror and Human Rights," International Studies Quarterly 53 (2009): 125-48.

[69] Anthony James Joes, Resisting Rebellion: The History and Politics of Counterinsurgency (Lexington, KY: University of Kentucky Press, 2004).

[70] Martha Crenshaw, “The Causes of Terrorism," Comparative Politics 13, no. 4 (1981): 379-99; Rosendorff and Sandler, 2004 (see note 31 above).

[71] Kristian Gleditsch, “Expanded Trade and GDP Data," Journal of Conflict Resolution 46, no. 5 (2002): 712 24.

[72] H. Urdal, “A Clash of Generations? Youth Bulges and Political Violence," International Studies Quarterly 50, no. 3 (2006): 607-29.

[73] Crenshaw (see note 53 above).

[74] Qvortrup and Lijphart (see note 23 above).

[75] The World Bank: World Development Indicators, http://data.worldbank.org/data-catalog/worlddevelopment-indicators (last accessed August 24, 2016).

[76] Li, (see note 48 above); Abdelaziz testas, "Determinants of Terrorism in the Muslim World: An Empirical Cross-Sectional Analysis," Terrorism and Political Violence 16, no. 2 (2004): 253-73.

[77] Alberto Abadie, "Poverty, Political Freedom, and the Roots of Terrorism," American Economic Review 96, no. 2 (2006): 50-56.

[78] Savun and Phillips (see note 48 above).

[79] J. P. Azam and A. Delacroix, "Aid and the Delegated Fight Against Terrorism," Review of Development Economics 10, no. 2 (2006): 330-44.

[80] We are interested in change within observations across time as well as between observations.

Additionally, since the occurrence of FCE is so rare (i.e. little variation in the independent variable of interest both within and between observations) it is difficult to determine which estimator is more appropriate. Clark and Linzer (2015) argue that correlation between the regressor and unit effects is an insufficient justification for fixed effects. As a robustness check we ran models using both fixed and random effects. The results are largely consistent between the two specifications, indicating that the impact of choice is minimal. For more information, see Tom S. Clark and Drew A. Linzer, "Should I Use Fixed or Random Effects?" Political Science Research and Methods 3, no. 2 (May 2015): 399-408.

[81] Walsh and Piazza 2010, (see note 3 above).

[82] Francis Fukuyama, "Women and the Evolution of World Politics," Foreign Affairs 77, no. 5 (1998): 24-40.

[83] Ibid.

[84] Rui J. P. Figueiredo and Barry R. Weingast, "Vicious Circles: Endogenous Political Extremism and Political Violence," Unpublished Manuscript. Available at http://faculty.haas.berkeley.edu/rui/m13.04.pdf (last accessed August 24, 2016). Crenshaw, (see note 53 above); Rosendorff and Sandler 2004, (see note 31 above).

[85] Bruce Hoffman, Inside Terrorism (New York: Columbia University Press, 2006). 


\section{Journal of Terrorism Research}

[86] C. Ortbals, M. Rinker, and C. Montoya, "Politics Closer to Home: The Impact of Subnational Institutions on Women in Politics," Publius: The Journal of Federalism 42, no. 1 (2012): 78-107.

[87] Lori Poloni-Staudinger and Candice Ortbals, "Gendering Abbottabad: Agency and Hegemonic Masculinity in an Age of Global Terrorism," Gender Issues 31 (2014): 34-57.

[88] Karla J. Cunningham, “Cross-Regional Trends in Female Terrorism," Studies in Conflict \& Terrorism 26 (2003): 171-95.

\section{About the authors}

Dr. Courtney Burns is an Assistant Professor of Political Science at Georgia Southern University.

Dr. Kyle Kattelman is an Assistant Professor of Political Science in the Department of Criminal Justice, Political Science \& International Affairs at Fairleigh Dickinson University. 